\title{
Gas Exchanges and Antioxidant Activity in Copaifera langsdorffii Desf. Seedlings after Flooding
}

\author{
Derek Brito Chaim Jardim Rosa ${ }^{1}$, Silvana de Paula Quintão Scalon ${ }^{2 *}$, \\ Thais Cremon ${ }^{1}$, Daiane Mugnol Dresch ${ }^{1}$
}

\begin{abstract}
${ }^{1}$ Faculty of Agricultural Sciences, Federal University of Grande Dourados, State Mato Grosso do Sul, Brazil
${ }^{2}$ Cnpq Productivity Scholarship, Faculty of Agricultural Sciences, Federal University of Grande Dourados, State Mato Grosso do Sul, Brazil

Email: derekrosa@gmail.com, ^silvanascalon@ufgd.edu.br, thaiscremon@outlook.com, daiamugnol@hotmail.com
\end{abstract}

How to cite this paper: Rosa, D.B.C.J., de Paula Quintão Scalon, S., Cremon, T. and Dresch, D.M. (2018) Gas Exchanges and Antioxidant Activity in Copaifera langsdorffii Desf. Seedlings after Flooding. American Journal of Plant Sciences, 9, 979-994. https://doi.org/10.4236/ajps.2018.95075

Received: March 6, 2018

Accepted: April 16, 2018

Published: April 19, 2018

Copyright (C) 2018 by authors and Scientific Research Publishing Inc. This work is licensed under the Creative Commons Attribution International License (CC BY 4.0).

http://creativecommons.org/licenses/by/4.0/

\begin{abstract}
The Copaifera langsdorffii Desf. seedlings, popularly known as "copaiba" or diesel tree, present a natural occurrence in the riparian forests of the Brazilian Cerrado, however, not much is known about their capacity to recover from flooding, particularly when the focus is on their establishment and use in programs for the recovery of degraded areas near watercourses and subject to flooding. The objective of this study was to evaluate over time the recovery of the efficiency of the photosynthetic apparatus and the antioxidant activity of C. langsdorffii seedlings flooded during different periods. The pots with the seedlings were placed in a plastic tank and submerged with water, and were removed from the flood condition every 21 days $(0,21,42,63$ and 84 days), and evaluated every 30 days (0, 30, 60, 90 and 120 days). The seedlings tolerated the flooding for up to 42 days, recovering after suspension of this condition. Seedlings flooded for 63 and 84 days showed lower recovery capacity after flooding, independently of the evaluation period. Under these conditions, lower efficiency of the photosynthetic apparatus, gas exchange, photo assimilate production and seedling quality were observed.
\end{abstract}

\section{Keywords}

Water Stress, Photosynthesis, Chlorophyll $A$ Fluorescence, Antioxidant Enzymes

\section{Introduction}

Riparian forests comprise areas covered by forests that are located in the margins of the rivers or streams and whose preservation is of paramount importance 
for the maintenance of the ecological and hydrological integrity of the aquatic systems. In addition, these forest formations exert a great influence on the water quality and the stabilization of the fauna and flora associated with this type of ecosystem. However, because they are widely exploited and degraded by anthropic action, given their ease of access, it is increasingly necessary to implement actions aiming their preservation or recovery [1] [2].

Regarding the procedures for the recovery and revegetation of riparian forests, one of the most important information to keep in mind is the ability of the seedlings to tolerate flooding conditions and their post-stress recovery potential. Therefore, the use of species tolerant to seasonal flooding, caused by the increase of the groundwater level in the rainy periods of the year, is a determining factor for the success of the recovery actions of this type of ecosystem. Although several variables are used to measure the plant's capacity to tolerate a stress condition due to flooding, most reforestation works in areas subject to flooding are based only on botanical surveys, while the correlations between stress and the physiological and metabolic responses are still underexplored [3] [4] [5].

Plants subjected to flooding may respond differently to this situation, depending on their intensity and duration, but some adaptation strategies are known, for example, changes in the relations of gas exchange, such as increased stomatal conductance, the reduction in photosynthesis, changes in transpiration rate and in water use efficiency that may remain even with the end of the stressful condition. In addition, changes in the photosynthetic apparatus and protection mechanisms associated with the activity of antioxidant enzymes also stand out [6] [7] [8] [9].

Copaifera langsdorffii Desf. seedlings, popularly known as copaiba or diesel tree, were the object of this study, and despite this species having a natural occurrence in the riparian forests of the Brazilian Cerrado, not much is known about its recovery capacity from flooding, particularly when the focus is on their establishment and use in programs for the recovery of degraded areas close to the watercourses, thus subject to flooding. Therefore, this study aimed to evaluate over time the recovery of the efficiency of the photosynthetic apparatus and the antioxidant activity of $C$. langsdorffii seedlings flooded during different periods, type styles are provided throughout this document and are identified in italic type, within parentheses, following the example. Some components, such as multi-leveled equations, graphics, and tables are not prescribed, although the various table text styles are provided. The formatter will need to create these components, incorporating the applicable criteria that follow.

\section{Materials and Methods}

The study was carried out in the Plant Nursery of the Faculty of Agrarian Sciences of the Federal University of Grande Dourados (UFGD), in the municipality of Dourados MS, during the months of November 2015 and May 2016. Copaifera langsdorffii Desf. seedlings with 90 days after emergence were used. 
The experiment was conducted in a completely randomized, $5 \times 5$ factorial design, with 5 flood periods $(0,21,42,63$ and 84 days) and 5 recovery times ( 0 , $30,60,90$ and 120 days) with four replicates. The experimental unit consisted of a pot with two seedlings each, a total of 8 plants.

In order to simulate flooding, the pots with the seedlings were placed in a plastic tank and submerged with water depths at a height of $2.0 \mathrm{~cm}$ from the substrate level and were removed from the flooding condition every 21 days $(0,21,42,63$ and 84 days), and evaluated only after the suspension of the flooding every 30 days $(0,30,60,90$ and 120 days after the suspension of the flooding). During the recovery time, the irrigation control was individualized using the gravimetric method, so that every two days the seedlings were irrigated with enough water to reach $75 \%$ of the water retention capacity of the system [10].

The substrate used to fill the 6-liter pots consisted of a mixture in equal volumes of Bioplant ${ }^{\circledR}$, vermiculite and Dystroferric Red Latosol (1:1:1 v/v). The flooding and recovery experiment was conducted in a nursery under $30 \%$ shading. During the recovery period, the seedlings previously flooded were evaluated at the leaf water potential $\left(\Psi_{\mathrm{w}}\right)$ obtained from readings held in individual sheets belonging to the second pair of fully expanded leaves the apex to the base, between 10 and 11:00 in the morning, using a pressure (Portable Plant Water Status Console-3115 model), immediately after collecting the leaves; the index of chlorophyll (SPAD); the potential quantum efficiency of photosystem II $\left(\mathrm{F}_{\mathrm{V}} / \mathrm{F}_{\mathrm{M}}\right)$, and the maximum efficiency of the photochemical processes in photosystem II $\left(\mathrm{F}_{\mathrm{V}} / \mathrm{F}_{\mathrm{O}}\right)$ and basal quantum production of the processes non-photochemical in PS II $\left(\mathrm{F}_{\mathrm{O}} / \mathrm{F}_{\mathrm{M}}\right)$, obtained from chlorophyll a fluorescence data, were measured using the portable fluorometer model OS-30p (Opti-Sciences Chlorophyll Fluorometer), Hudson, USA). Photosynthetic $(A)$ and transpiration rates $(E)$, stomatal conductance $(g s)$, internal carbono dioxide concentration $(C i)$, water use efficiency ( $W U E)$, carboxylation efficiency of Rubisco $(A / C i)$, and intrinsic water use efficiency (IWUE) were determined using the infrared gas analyzer (IRGA), ADC, model LCi PRO. The evaluation was performed using four seedlings per treatment, in the morning, between 08:00 and 11:00 h, in fully expanded leaves that were previously marked, and all measurements were performed on the same leaves, and only the data measured under a photosynthetic photon flux (PPF) higher than $700 \mathrm{mmol} \cdot \mathrm{m}^{-2} \cdot \mathrm{s}^{-1}$ was considered. The number of leaves were also evaluated, whereas the leaf area was measured using a $\mathrm{LI}^{-} \mathrm{COR}^{\circledR}$ area meter, model LI 3100; the Dickson Quality Index (DQI) [11] and, finally, the activity of the antioxidant enzymes superoxide dismutase and peroxidase in plant tissues of leaves and roots were also evaluated according to the methodology described by Broetto [12].

Temperature and relative humidity data during the experimental period were obtained from the Embrapa Agropecuária Oeste Meteorological Station, in Dourados MS (Figure 1). For the analysis of the results, the statistical program 


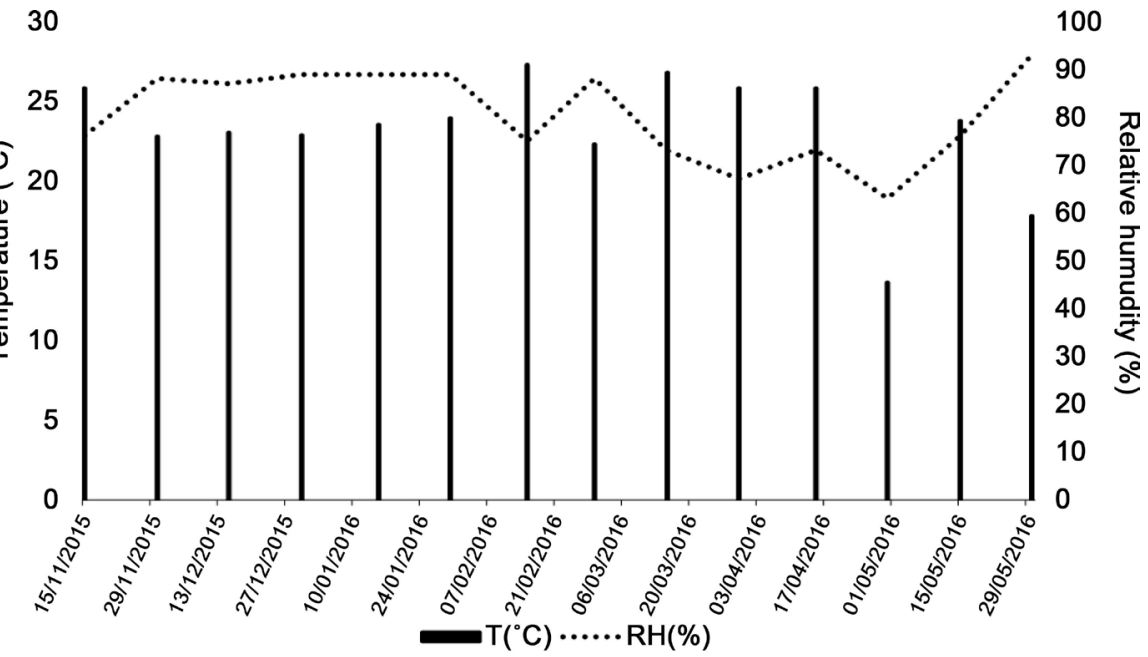

Figure 1. Temperature and relative humudity during the experimental period.

SISVAR 5.6 [13] was used and the data were submitted to analysis of variance and adjusted by regression equations, when F-test at 5\% significance level.

\section{Results}

There was a significant interaction $(\mathrm{p}<0.05)$ between the flooding period and the recovery time for all the characteristics, except for the leaf water potential $(\Psi \mathrm{w})$, which presented an isolated event $(\mathrm{p}<0.05)$ for the flooding period and recovery time. The water potential of the leaves had a minimum value of -1.68 $\mathrm{MPa}$ at 39.4 days of flooding and $-2.00 \mathrm{MPa}$ at 67.2 days of recovery (Figure 2(a) and Figure 2(b)).

The liquid photosynthesis $(A)$ (Figure 3(a)) continued to increase for the seedlings subjected to flooding for up to 42 days, presenting a maximum value at 120 days of recovery $\left(4.23 \mu \mathrm{mol} \cdot \mathrm{m}^{-2} \cdot \mathrm{s}^{-1}\right)$. On the other hand, seedlings subjected to flooding for 63 and 84 days showed decreasing photosynthetic rates throughout the evaluations. Similar result was also observed for transpiration (Figure 3(b)), and the seedlings subjected to flooding for 63 and 84 days had decreasing values and those whose permanence in the flooding conditions were 0,21 and 42 days presented increasing values for this variable. Regarding water use efficiency ( $W U E$ ), the seedlings subjected to 42 days of flooding also presented increasing values, with a higher value at 120 days of recovery $\left(2.10 \mu \mathrm{mol} \mathrm{CO}_{2} \mathrm{mmol}^{-1} \mathrm{H}_{2} \mathrm{O}\right)$ (Figure 3(c)). Seedlings subjected to 63 days of flooding presented the worst $W U E$ values after 30 days of recovery when compared to the seedlings subjected to other flooding periods.

The internal carbon values $(C \hat{i})$ of the seedlings subjected to flooding for 63 and 84 days were higher than those seedlings flooded for the shortest period when evaluated at 120 days and, generally, the lowest values were observed in the 42 days of flooding during all evaluations (Figure 4(a)). The carboxylation efficiency of the Rubisco - $A / C i$ (Figure 4(b)) was increasing throughout the recovery period for the flooded seedlings for 42 days and the highest value was 
observed at 120 days $\left(0.014 \mu \mathrm{mol} \cdot \mathrm{m}^{-1} \cdot \mathrm{s}^{-1}\right)$. On the other hand, in seedlings exposed to flooding for 63 and 84 days, the values decreased throughout the recovery time.

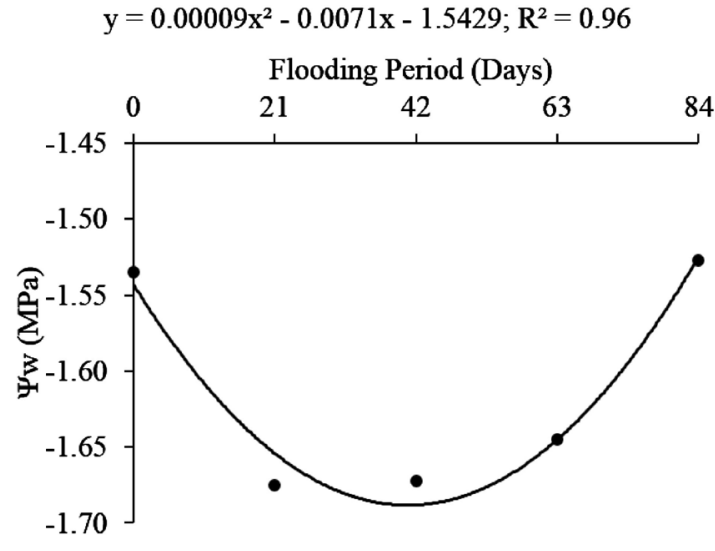

(a)

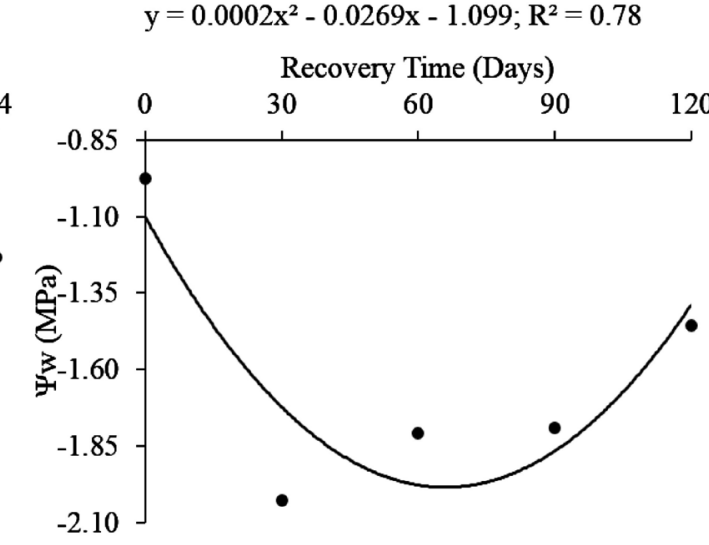

(b)

Figure 2. Water potential $\left(\Psi_{\mathrm{w}}\right)$ of Copaifera langsdorffii Desf. leaves in function of flooding period (a) and of recovery time (b).

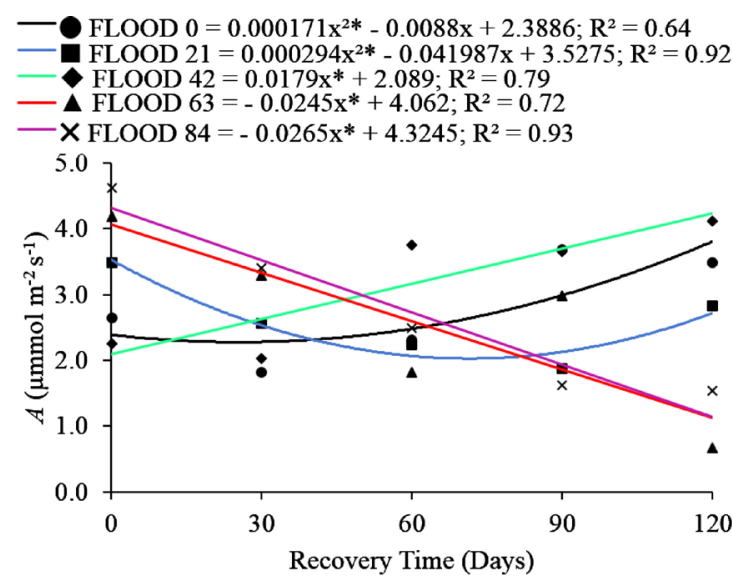

(a)
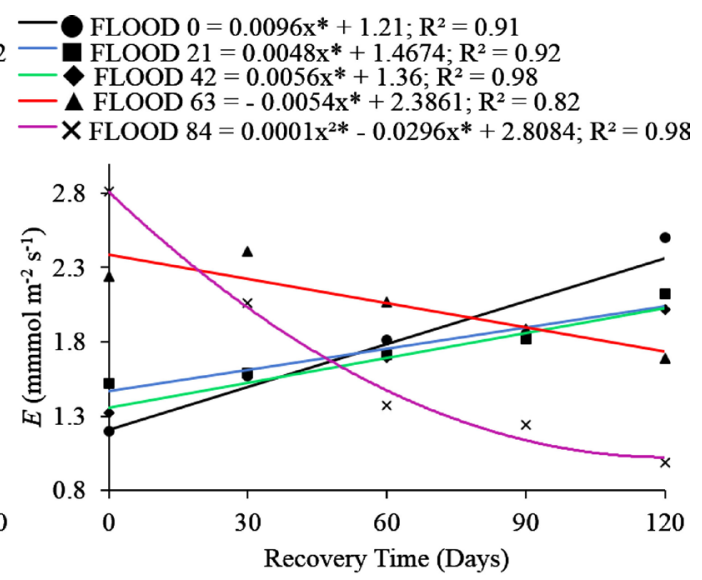

(b)
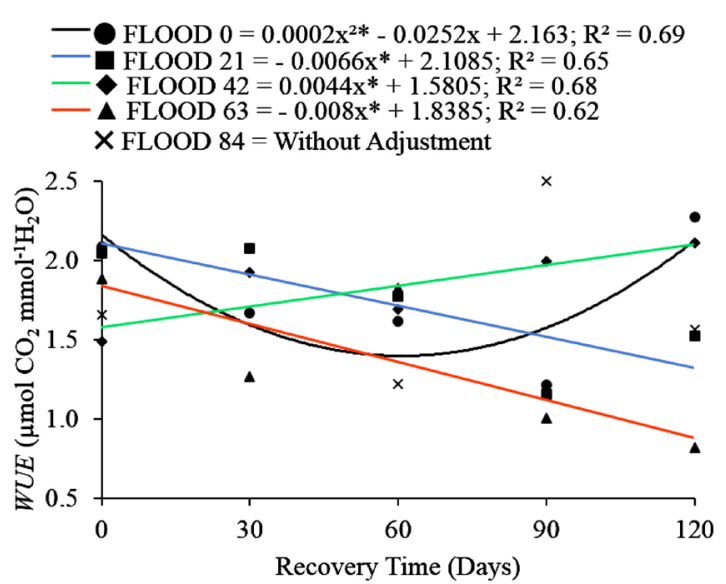

(c)

Figure 3. Liquid photosynthesis $A$ (a); transpiration $E(\mathrm{~b})$ and water use efficiency $W U E(\mathrm{c})$ in seedlings of Copaifera langsdorffi Desf. depending on the flooding period (FLOOD) and the recovery time. 


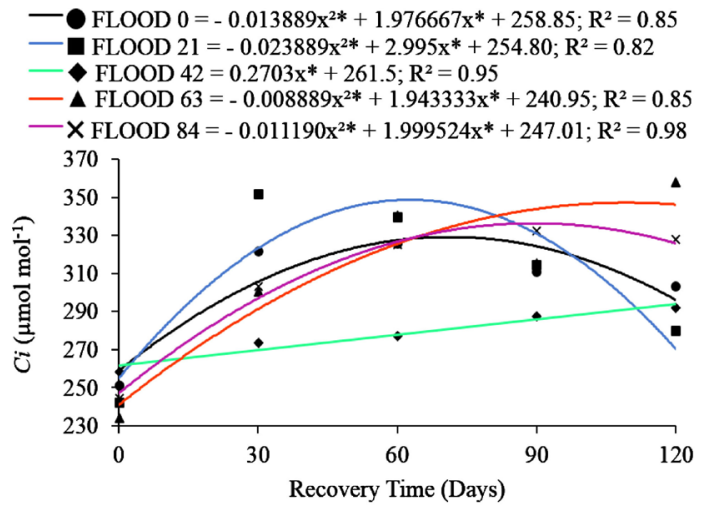

(a)

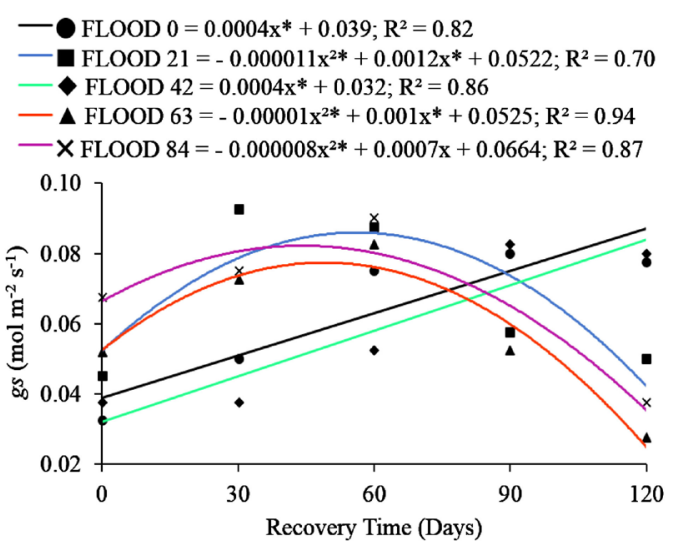

(c)

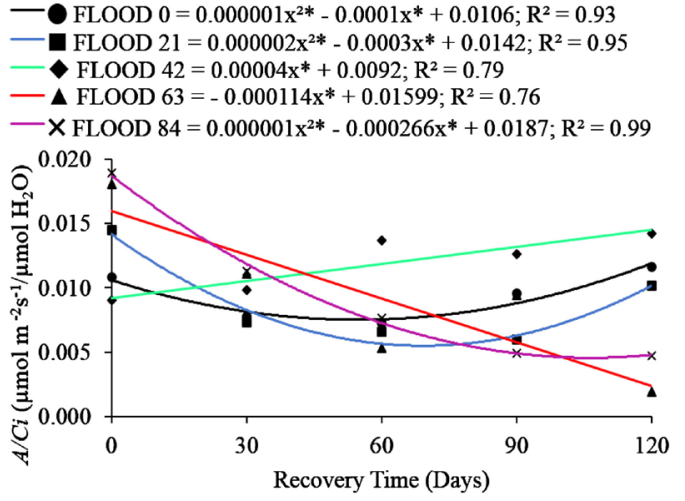

(b)

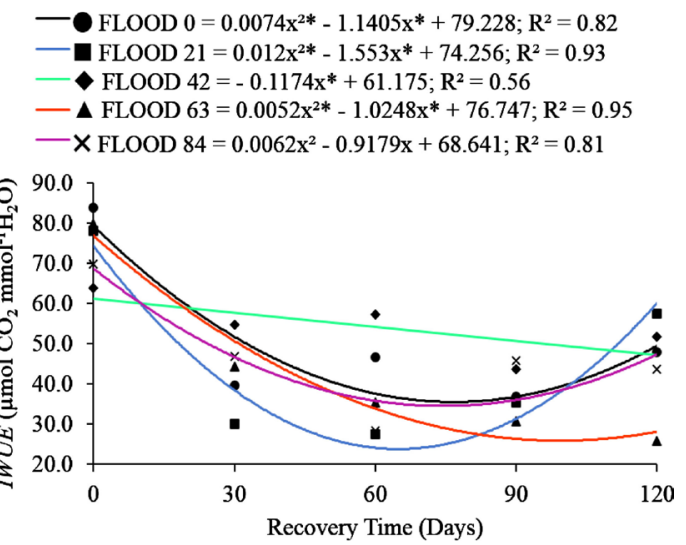

(d)

Figure 4. Internal carbon values $C i$ (a); carboxylation efficiency of the Rubisco $A / C i$ (b); stomatal conductance $g s(\mathrm{c})$ e intrinsic water use efficiency $I W U E(\mathrm{~d})$ in seedlings of Copaifera langsdorffi Desf. depending on the flooding period (FLOOD) and the recovery time.

Increasing values of stomatal conductance $(g s)$ (Figure 4(c)) were observed throughout the recovery period in the non-flooded ( 0 days) and flooded seedlings for 42 days and for the other conditions, the values were decreasing after 60 days of recovery. In general, values of intrinsic water use efficiency (IWUE) were higher throughout the recovery time for the seedlings subjected to flooding for 42 days. Seedlings flooded for 63 days presented the lowest values for this variable after 90 days of recovery (Figure 4(d)).

For the characteristics related to chlorophyll a fluorescence (Figure 5), a similar pattern was observed between the seedlings subjected to flooding condition for 42 days and those that were not flooded, and among those seedlings subjected to flooding by 63 and 84 days. Moreover, the difference between the two groups (flooded for 0 and 42 days and flooded by 63 and 84 days) for $F_{V} / F_{M}$ (Figure 5(a)), $\mathrm{F}_{\mathrm{O}} / \mathrm{F}_{\mathrm{M}}$ (Figure $5(\mathrm{~b})$ ) and $\mathrm{F}_{\mathrm{O}} / \mathrm{F}_{\mathrm{M}}$ (Figure $5(\mathrm{c})$ ) increased gradually after 60 days of recovery. At 120 days of recovery, the calculated values of $\mathrm{F}_{\mathrm{V}} / \mathrm{F}_{\mathrm{M}}$, $\mathrm{F}_{\mathrm{V}} / \mathrm{F}_{\mathrm{O}}$ and $\mathrm{F}_{\mathrm{O}} / \mathrm{F}_{\mathrm{M}}$ for C. langsdorffii seedlings flooded for 42 days were $0.707 ; 2.47$ and 0.32 , respectively, which are very close to those values calculated for the seedlings that were not flooded (0.708, 2.41 and 0.29 , respectively).

As for the activity of the superoxide dismutase enzyme in the leaves of 


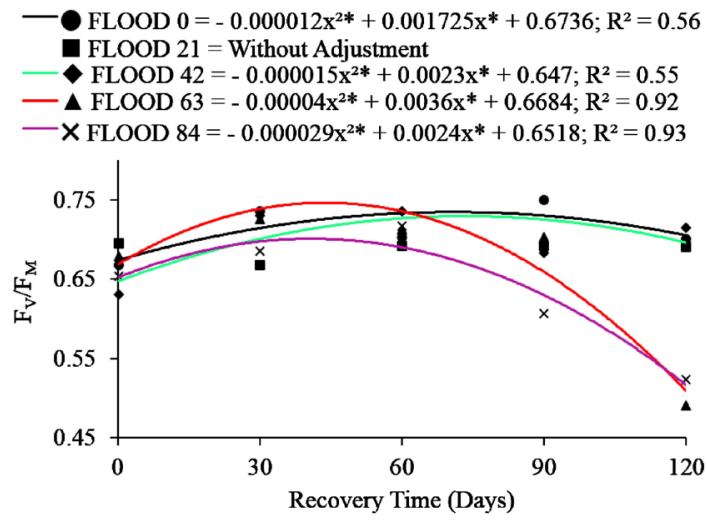

(a)

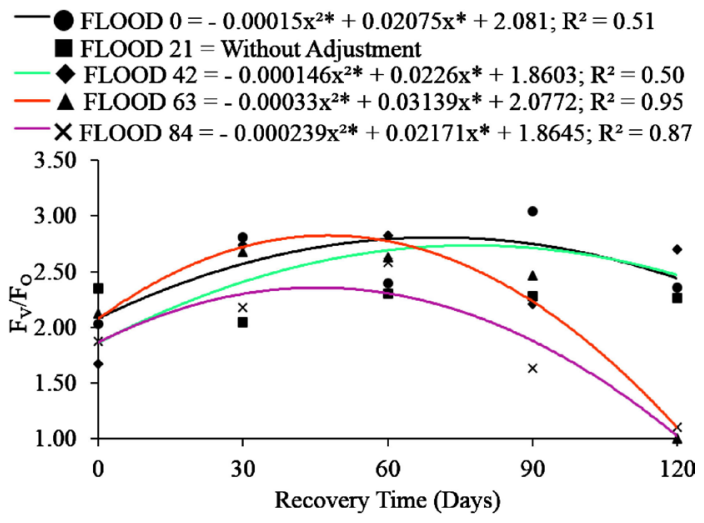

(b)

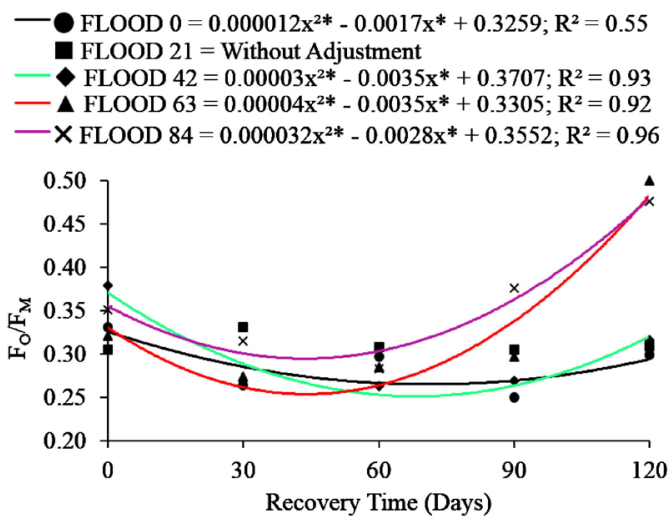

(c)

Figure 5. Potential quantum efficiency of photosystem II $F_{V} / F_{M}(A)$; maximum efficiency of the photochemical processes in photosystem II $\mathrm{F}_{\mathrm{V}} / \mathrm{F}_{\mathrm{O}}$ (B) and basal quantum production of the processes non-photochemical in photosystem II $\mathrm{F}_{\mathrm{O}} / \mathrm{F}_{\mathrm{M}}(\mathrm{C})$ in seedlings of Copaifera langsdorffi Desf. depending on the flooding period (FLOOD) and the recovery time (days).

C. langsdorffii (SOD leaves), it was observed that the values were higher after removal of the flooding in seedlings flooded for 42 and 63 days and at 30 days of recovery, and subsequently declined over the course of 120 days. On the other hand, for the seedlings subjected to 84 days of flooding the SOD activity in the leaves remained unchanged with the course of the evaluations after flooding (Figure 6(a)). Similar results, however with lower magnitude, was recorded in the activity of superoxide dismutase in the roots (SOD roots). Seedlings flooded for 42 days also maintained high values of this enzyme in the roots until approximately 30 days of recovery, whereas for those subjected to flooding for 63 and 84 days, the values did not change much during the recovery evaluations (Figure 6(b)).

Regarding the peroxidase (POD) enzymatic activity, the effects of the treatments were more intense in the roots (Figure 6(d)) than in the leaves (Figure $6(\mathrm{c}))$. This fact is evidenced by the amplitude of the enzymatic activity, since in the roots the value was approximately $1.86 \mu \mathrm{Kat} \mu \mathrm{g} \cdot \operatorname{Prot}^{-1}$, whereas in the leaves, the variation was approximately $0.23 \mu \mathrm{Kat} \mu \mathrm{g} \cdot$ Prot $^{-1}$, regardless of the treatments evaluated. In seedlings flooded for 42 days, root peroxidase (POD roots) values 


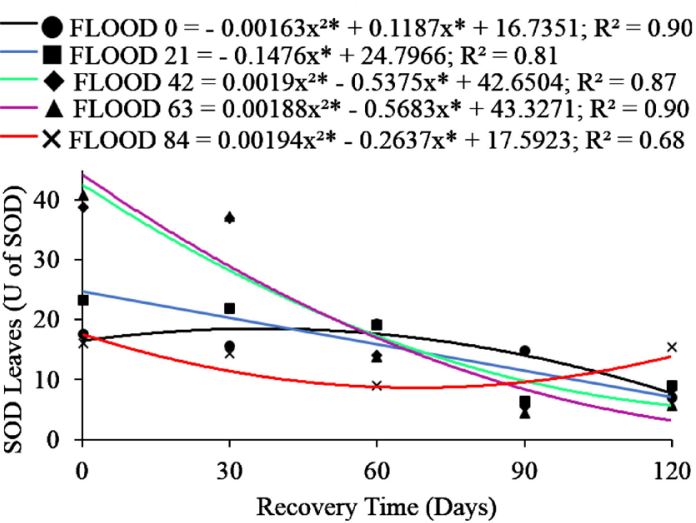

(a)
FLOOD $0=$ Without Adjustment

FLOOD $21=0.0009 \mathrm{x}^{2 *}-0.17125 \mathrm{x} *+9.950867 \cdot \mathrm{R}^{2}=0.90$

FLOOD $42=0.00039 x^{2 *}-0.05382 x *+3.3547 ; R^{2}=0.96$

FLOOD $63=0.00082 \mathrm{x}^{2 *}-0.1292 \mathrm{x} * 6.2443 ; \mathrm{R}^{2}=0.92$

X FLOOD $84=0.000306 x^{2 *}-0.03686 x *+2.5552 ; R^{2}=0.88$

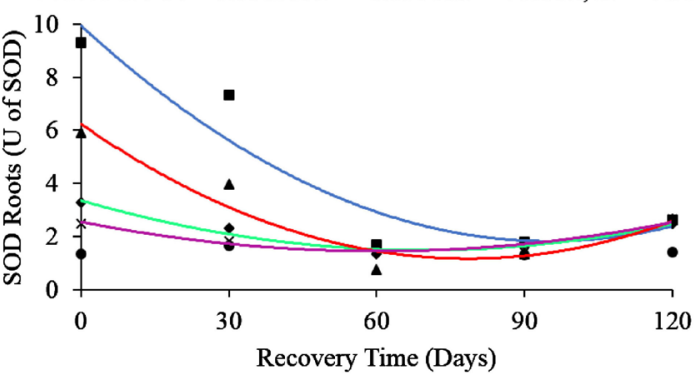

(b)

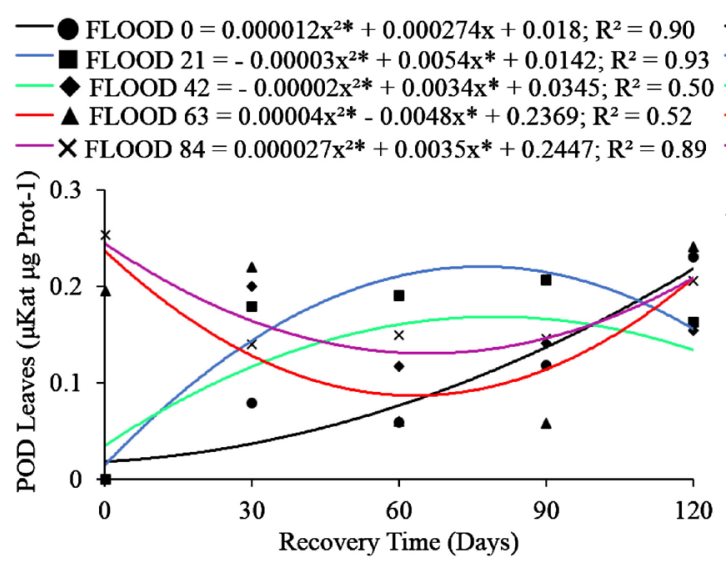

(c)

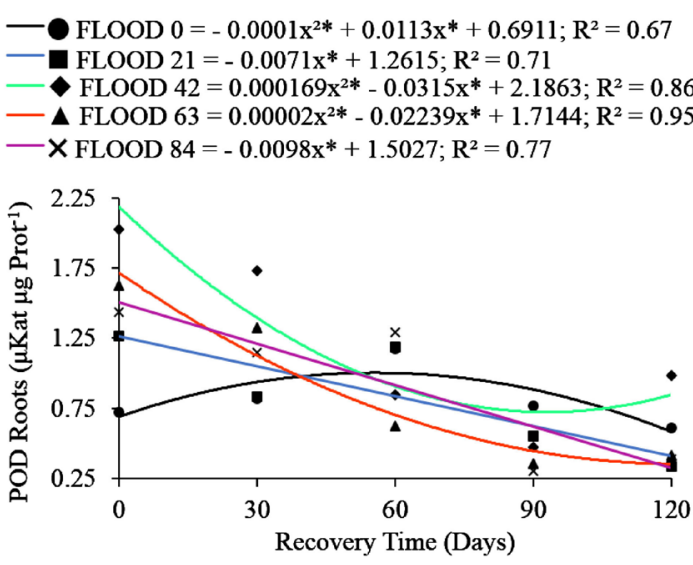

(d)

Figure 6. Enzimatic activity of superoxide dismutase in leaves (SOD Leaves) (a) and roots (SOD roots) (b); of peroxidase in leaves (POD Leaves) (c) and roots (POD Roots) (d) in seedlings of Copaifera langsdorffi Desf. depending on the flooding period (FLOOD) and the recovery time (days).

were higher during the recovery period, particularly at 0,30 and 120 days of recovery (Figure 6(d)).

The $C$. langsdorffii seedlings showed a gradual increase of the leaf area during the recovery period, except for the seedlings that were flooded for 84 days. The values were more expressive in the seedlings flooded for 42 and 63 days, particularly after 90 days of recovery (Figure $7(\mathrm{a})$ ).

Regarding the number of leaves (Figure 7(b)), the lowest value was 6.01 leaves per plant ${ }^{-1}$ for seedling flooded for 84 days soon after removal of the flooding condition, however, they were increasing over time but did not remain at the end of the evaluation period. The number of leaves of the non-flooded seedlings was approximately 6.84 leaves per plant- 1 throughout the evaluation period. The number of leaves for seedling flooded for 42 and 63 days was greater than 8.26 leaves per plant- 1 soon after the removal of the flooding condition, and similar result for seedlings flooded for 84 days was also observed for seedling flooded for 63 days. In the seedlings flooded for 42 days, maximum values were observed at 93 days of recovery (12.6 leaves per.plant ${ }^{-1}$ ).

Regarding the Dickson Quality Index (DQI), the values increased throughout 


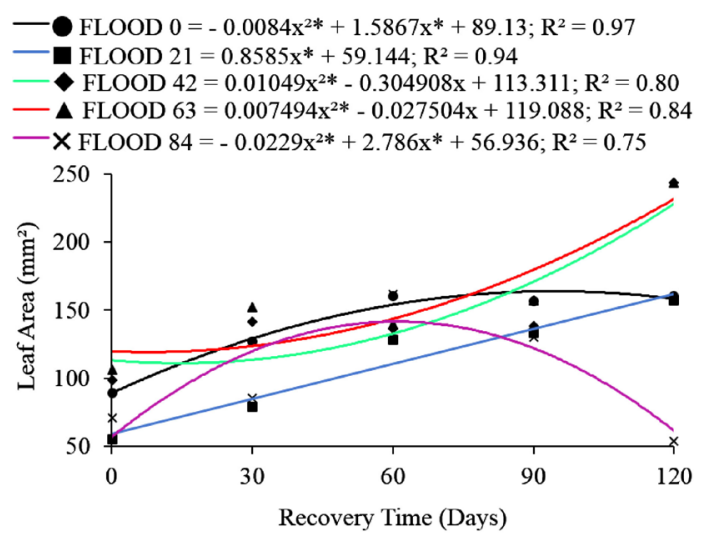

(a)

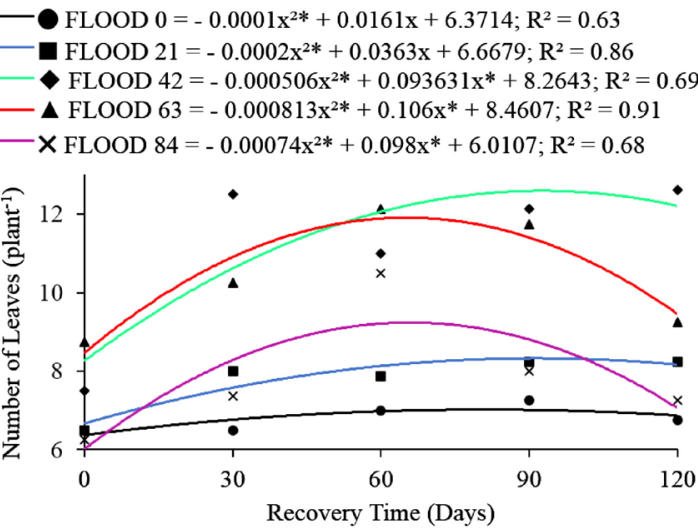

(b)

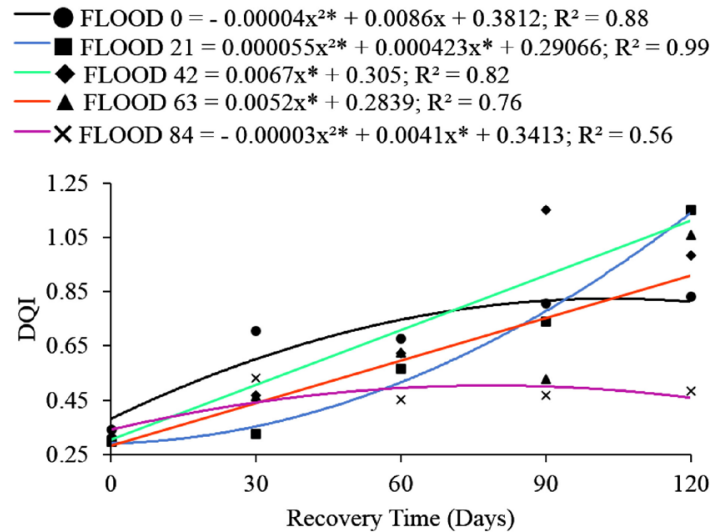

(c)

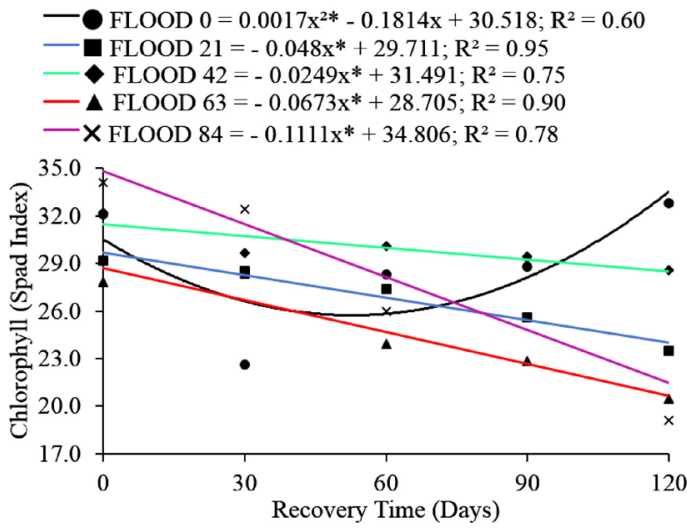

(d)

Figure 7. Leaf area (a); Number of leaves (b); Dickson Quality Index DQI (c) and chlorophyll (d) in seedlings of Copaifera langsdorffi Desf. depending on the flooding period (FLOOD) and the recovery time (days).

the recovery period for the seedlings flooded for 42 days and the less expressive results were observed in seedlings flooded for 84 days, mainly after 60 days of recovery (Figure $7(\mathrm{c})$ ). Chlorophyll values (Figure $7(\mathrm{~d})$ ) were generally higher for seedlings flooded for 42 days and decreases in these values were observed in the seedlings flooded for 63 and 84 days throughout the recovery period in which the seedlings were evaluated.

\section{Discussion}

In the leaves of seedlings of Copaifera langsdorffi Sp. the minimum values for the water potential $\left(\Psi_{\mathrm{w}}\right)$ depending on the period of flooding and the recovery assessment periods (Figure 2) are less than-1.5 MPa, which is considered a critical threshold for the development of plants and that may have affected negatively the photosynthesis by the end of the experimental period (Figure 3(a)). Such $\Psi_{\mathrm{w}}$ values are considered critical to the development of woody species of the Brazilian Cerrado, affecting various physiological processes, which can compromise the growth and productivity of the species [14] [15] [16]. However, plants in all periods of flooding showed water potential recovery that allowed the resumption of photosynthetic metabolism. 
Considering that liquid photosynthesis $(A)$ was decreasing throughout the evaluations for the seedlings subjected to flooding for periods of 63 and 84 days (Figure 3(a)), we suggest that periods of flooding above these are damaging to the maintenance of a regular photosynthetic rate for this species, which is clear with the abrupt drop of the values of this characteristic in the first 30 days of recovery. Similar result was also observed for transpiration $(E)$ (Figure 3(b)), which after the removal of these plants from the flooding condition, values were still higher than the other treatments, which were not stable throughout the recovery time. A consequence of this can be observed in the Figure 3(c), when evaluating the constant decrease in water use efficiency of the seedlings subjected to flooding for 63 days. The values were therefore also decreasing throughout the recovery time.

On the other hand, the seedlings subjected to flooding for 42 days presented increasing values at the time of the entire recovery time for photosynthesis, transpiration and WUE, demonstrating that if exposed to excess water conditions for approximately 40 days, the species may to recover when the stress condition ceases and present results for these three variables very close and even higher than those of the plants that were not flooded. In addition, it is known that higher values of $W U E$ indicate greater physiological plasticity before the biotic and abiotic adversities that the species are exposed [17] [18].

The lower internal carbon values in the seedlings after exposure to flooding for 42 days associated with the greater carboxylation efficiency of Rubisco and consequently greater photosynthesis suggest a higher recovery efficiency after the removal of flooding condition, unlike the seedlings flooded for 63 and 84 days, whose internal carbon values were generally higher throughout the recovery time (Figure 4(a)). Higher internal carbon concentrations confirm the lower photosynthesis production and the decreasing pattern of Rubisco carboxylation efficiency $(A / C \hat{I})$ of seedlings flooded for a longer period of time (Figure 4(b)). Lower values of $\mathrm{A} / \mathrm{Ci}$ may be due to the damages caused by prolonged conditions of lack of oxygen in the substrate in the photosynthetic apparatus of the seedlings exposed to flooding for a longer period of time, which may compromise and reduce Rubisco's activity [19] [20]. The reduction of photosynthesis may be attributed to stomatal closure and factors of the photochemical stage of photosynthesis, such as the aforementioned increase in internal carbon concentration [21] [22].

As for the stomatal conductance $(g s)$, the values were increasing during the whole recovery time for seedlings flooded for 42 days and different pattern was observed in the seedlings exposed to flooding for 63 and 84 days. In these, maintenance of high stomatal conductance rates declined after 60 days of recovery, suggesting that the seedlings did not reach an ideal recovery level for this variable (Figure 4(c)) and, in addition, this situation also justifies the lower photosynthetic rates during the same time. It is known that some plants subjected to flooding tend to present responses similar to those observed for $C$. 
langsdorffii. Lonchocarpus sericeus (Poir.) Kunth ex DC, when subjected to flooding for 60 and 90 days, for example, presented a reduction in stomatal conductance and an increase in the internal carbon concentration, and consequently a decrease in the photosynthetic rate [5].

The values for intrinsic water use efficiency (IWUE) were also higher in the $C$. langsdorffii seedlings flooded for 42 days, indicating that this condition was the most favorable for the maintenance of the gas exchanges of these plants, since the photosynthetic rate remained high even with reduction of stomatal conductance (Figure 4(d)). The maintenance of high IWUE values during the recovery of the seedlings after flooding reinforces the fact that seedlings tolerate flooding for approximately 40 days, since the increasing in this parameter leads to greater capacity of the plants to establish themselves and survive in stress environments [23] [24].

Concerning the variables related to chlorophyll a fluorescence (Figure 5), it is observed that, regardless of which one is analyzed, there was a very distinct difference, mainly after 60 days of recovery, in seedlings flooded for up to 42 days and seedlings flooded for more than 63 days. It is known that the reference values for the potential quantum efficiency of photosystem II $\left(\mathrm{F}_{\mathrm{V}} / \mathrm{F}_{\mathrm{M}}\right)$ oscillate between 0.750 and 0.850 [25] when the reaction centers of photosystem II are intact, however, such values are subject to a variation margin, which depends, among other factors, on the species under study, on its physiological mechanisms and on its growth site [26] [27]. On the other hand, much lower values, such as those observed for $C$. langsdorffii seedlings flooded for a longer period of time (Figure 5(a)), are suggestive of the occurrence of photoinhibitory damage to the reaction centers of photosystem II, which implies, as previously observed, in sharp decreases in photosynthesis. Similar results were observed in Populus deltoides $\mathrm{W}$. Bartram ex Marshall, with significant decreases in $\mathrm{F}_{\mathrm{V}} / \mathrm{F}_{\mathrm{M}}$ and photosynthetic rate in severe flooding conditions (140 days) during winter time [28].

Similarly, very sharp reductions in the maximum efficiency values of the photochemical process in photosystem II $\left(\mathrm{F}_{\mathrm{V}} / \mathrm{F}_{\mathrm{O}}\right)$ also confirm losses to the photosynthetic apparatus of the plants. This relationship, since it is an indicator more sensitive to the changes in functionality of photosystem II, is used to amplify the small variations detected in the $F_{V} / F_{M}$ [29]. The reference values for $F_{V} / F_{O}$ reflect that the maintenance of the adequate state of functionality of the reaction centers of photosystem II is between 4 and 6 [30]. In this study, the average values observed for non-flooded (and, theoretically, not stressed) plants were located in a zone inferior to the reference values, suggesting, first, that the species has a different reference margin than the one conventionally adopted. In a second analysis, it was observed that $C$. langsdorffii seedlings flooded for 42 days also had their $F_{V} / F_{O}$ values very close throughout the recovery period from those that were not flooded and gradually increased over time, an indicative of recovery from flooding. The opposite effect was observed in seedlings that were flooded for 63 and 84 days, particularly after 60 days of recovery, which indicates that 
the seedlings suffered damage possibly irrecoverable to the photosynthetic apparatus (Figure 5(b)).

For basal quantum production of the non-photochemical processes of photosystem II $\left(\mathrm{F}_{\mathrm{O}} / \mathrm{F}_{\mathrm{M}}\right)$, as observed for $\mathrm{F}_{\mathrm{V}} / \mathrm{F}_{\mathrm{M}}$ and $\mathrm{F}_{\mathrm{V}} / \mathrm{F}_{\mathrm{O}}$, the values of $\mathrm{F}_{\mathrm{O}} / \mathrm{F}_{\mathrm{M}}$ for non-flooded and flooded seedlings for 42 days were also distant from the reference margin, however, this difference was significantly greater in seedlings flooded for more than 63 days, whose results were close to 0.50 at 120 days of recovery (Figure 5(c)), indicating damages in photosystem II, which reflected the low rates of photosynthesis for these conditions throughout the evaluations. The average reference values for this characteristic are between 0.14 and 0.20 and several authors suggest that the increase in this relation is indicative of stress [30].

Regarding the activity of the superoxide dismutase in the foliar and root tissues of the C. langsdorffii seedlings (Figure 6(a) and Figure 6(b)), it can be observed that, although they presented similar results, particularly in those seedlings flooded for 42 and 84 days throughout the experiment, the differences were more expressive in the leaves than in the roots, which allows to infer that this enzyme assumes different functions in different organs or cell compartments of the plants with different routes to the best adaptation to the environment [31] [32]. In the seedlings flooded for 42 days, it was observed that the enzymatic activity was more intense soon after the removal of the flooding condition suggesting a protective adaptation to this type of stress, which is confirmed, over time, with the decrease of these values, approaching the values of the non-flooded and theoretically non-stressed seedlings. When flooded for 84 days, the seedlings maintained lower SOD values in relation to the other treatments, suggesting a possible collapse in the structure protecting the reactive oxygen species (ROS), indicating that these seedlings had their protective mechanisms damaged.

Contrary to what occurred with SOD activity, the values for peroxidase activity were more significant in the roots of $C$. langsdorffii than in its leaves (F Figure 6(c) and Figure 6(d)). In addition, they were higher in the roots of the seedlings flooded for 42 days when compared to the others, approaching the values obtained for those non-flooded seedlings after 60 days of recovery. It was also observed that seedlings flooded for 63 and 84 days presented higher values for this characteristic soon after the removal of the flooding condition and that these became inferior to those of the non-flooded seedlings after 60 days of recovery, indicating, as observed for the SOD activity a possible destabilization of this route of stress protection in these seedlings. It is known that adaptations to the different types of stress may be linked to the ability of plants to produce and activate antioxidative agents within their tissues in order to combat ROS. Among these antioxidative agents, the enzymes superoxide dismutase and peroxidase stand out, since the increase of their enzymatic activities is an important parameter to quantify the protection response of plants to the stress caused by flooding [7] [31] [32]. In particular, some peroxidases, which are involved in various physiological functions, are induced in plants after exposure to flooding 
or to drought [33] [34].

It was observed that the leaf area (Figure $7(a)$ ) increased for all the treatments during the recovery time, except for the flooded leaves for 84 days, which could not maintain constant the value for this characteristic. This became more evident when compared to the number of leaves (Figure $7(b)$ ) of these plants after 60 days of recovery, after which the values decreased as a function of foliar abscission. It is known that under severe stress conditions due to flooding many species, in order to compensate the low availability of energy and supplies, reallocate their photoassimilates and stop assigning them, for example, to the formation of new shoots, leaves and also for the expansion of the leaf area [35], a fact that probably occurred with those $C$. langsdorffii seedlings that were exposed to flooding for a longer period of time and that, during the recovery period, could not recover their leaf area when compared to the non-flooded seedlings.

The chlorophyll values of seedlings flooded for 63 and 84 days also decreased during the whole recovery period (Figure $7(\mathrm{c})$ ), a direct expression of the damages caused by flooding, since conditions of water stress can favor the reduction of the contents of the photosynthetic pigments due to the oxidative damages they cause [36]. However, it is important to note that leaf yellowing (chlorosis), a characteristic sign of chlorophyll degradation, was not observed, therefore, the decrease of chlorophyll contents in the flooded seedlings for a longer period of time was a direct response to the decrease in the metabolism of these plants, which consequently, synthesized fewer of these pigments.

Regarding the Dickson quality index (DQI), it was observed that, in general, the flooded leaves for 84 days had the lowest values for this characteristic throughout the recovery period and, in the other conditions, the values were increasing over time (Figure $7(\mathrm{~d})$ ). Although the observed values for all treatments were higher than the recommended minimum of 0.20 [11], it is known that higher DQI values indicate better seedling quality, allowing to infer greater robustness and adequate distribution of biomass in the seedling, factors that help in determining the recovery of these plants after stress caused by flooding [37] [38]. Such information, added to the others already discussed in this study, corroborate the idea that $C$. langsdorffii seedlings flooded for long periods have its metabolism damaged and consequently its growth, failing to recover when compared to non-flooded ones, or those flooded for a shorter period of time.

\section{Conclusions}

Copaifera langsdorffii Desf. seedlings tolerate flooding for up to 42 days, recovering after removal of flooding condition, all the evaluated characteristics, which represent a characteristic pattern of stress, reaching values similar or superior to those of non-flooded seedlings.

Seedlings flooded for 63 and 84 days showed lower recovery capacity after flooding, regardless of the evaluation period. Under these conditions, lower effi- 
ciency of the photosynthetic apparatus, gas exchange, photoassimilate production and seedling quality were observed.

\section{References}

[1] Lopes, S.F. and Schiavini, I. (2007) Dinâmica da comunidade arbórea de mata de galeria da Estação Ecológica do Panga, Minas Gerais, Brasil. Acta Botanica Brasilica, 21, 249-261. https://doi.org/10.1590/S0102-33062007000200001

[2] Fontes, C.G. and Walter, B.M.T. (2011) Dinâmica do componente arbóreo de uma mata de galeria inundável (Brasília, Distrito Federal) em um período de oito anos. Revista Brasileira de Botânica, 34, 145-158. https://doi.org/10.1590/S0100-84042011000200002

[3] Ferreira, W.C., Botelho, S.A., Davide, A.C. and Faria, J.M.R. (2009) Estabelecimento de mata ciliar às margens do reservatório da usina hidroelétrica de Camargos, MG. Ciência Florestal, 19, 69-81. https://doi.org/10.5902/19805098421

[4] Lacerda, V.A., Barbosa, F.M., Soares, J.J. and Barbosa, M.R.V. (2010) Flora arbustiva-arbórea de três áreas ribeirinhas no semiárido paraibano, Brasil. Biota Neotropical, 10, 275-284. https://doi.org/10.1590/S1676-06032010000400032

[5] Lira, J.M.S., Ferreira, R.A., Silva Junior, C.D., Santos Neto, E.M. and Santana, W.S. (2013) Análise de crescimento e trocas gasosas de plantas de Lonchocarpus sericeus (Poir.) D.C. sob alagamento para uso na recuperação de matas de ciliares. Ciência Florestal, 23, 655-665. https://doi.org/10.5902/1980509812349

[6] Pareek, A., Sopory, S.K., Bohnert, H.J. and Govindjee (2010) Abiotic Stress Adaptation in Plants: Physiological Molecular and Genomic Foundation. Springer, Dordrecht.

[7] Pompelli, M.F., Barata-Luís, R., Vitorino, H.S., Gonçalves, E.R., Rolim, E.V., Santos, M.G., Almeida-Cortez, J.S., Ferreira, V.M., Lemos, E.E. and Endres, L. (2010) Photosynthesis, Photoprotection and Antioxidant Activity of Purging Nut under Drought Deficit and Recovery. Biomass and Bioenergy, 34, 1207-1215. https://doi.org/10.1016/j.biombioe.2010.03.011

[8] Campello, D.H., Lacerda, C.F., Sousa, J.A., Correia, D., Bezerra, A.M.E., Araújo, J.D.M. and Neves, A.L.R. (2015) Trocas gasosas e eficiência do fotossistema II em plantas adultas de seis espécies florestais em função do suprimento de água no solo. Revista Árvore, 39, 973-983. https://doi.org/10.1590/0100-67622015000500020

[9] Oliveira, A.K.M. and Gualtieri, S.C.J. (2016) Gas Exchange in Young Plants of Tabebuia aurea (Bignoniaceae Juss.) Subjected to Flooding Stress. Revista Árvore, 40, 39-49. https://doi.org/10.1590/0100-67622016000100005

[10] Souza, C.C., Oliveira, F.A., Silva, I.F. and Amorim Neto, M.S. (2000) Recuperação de métodos de determinação de água disponível e manejo da irrigação em terra roxa sob cultivo de algodoeiro herbáceo. Revista Brasileira de Engenharia Agrícola e Ambiental, 4, 338-342. https://doi.org/10.1590/S1415-43662000000300006

[11] Dickson, A., Leaf, A.L. and Hosner, J.F. (1960) Quality Appraisal of White Spruce and White Pine Seedling Stock in Nurseries. Forestry Chronicle, 36, 10-13. https://doi.org/10.5558/tfc36010-1

[12] Broetto, F. (2014) Métodos de trabalho em bioquímica vegetal e tecnologia de enzimas. UNESP, São Paulo.

[13] Ferreira, D.F. (2014) Sisvar: A Guide for Its Bootstrap Procedures in Multiple Comparisons. Ciência e Agrotecnologia, 38, 109-112. https://doi.org/10.1590/S1413-70542014000200001 
[14] Franco, A.C., Bustamante, M., Caldas, L.S., Goldstein, G., Meinzer, F.C., Kozovits, A.R., Rundel, P. and Corandin, V.T.R. (2005) Leaf Functional Traits of Neotropical savanna Trees in Relation to Seasonal Water Deficit. Trees, 19, 326-335. https://link.springer.com/article/10.1007\%2Fs00468-004-0394-z https://doi.org/10.1007/s00468-004-0394-Z

[15] Kumar, A. and Singh, D.P. (1998) Use of Physiological Indices as a Screening Technique for Drought to Tolerance in Oilseed Brassica Species. Annals of Botany, 81, 413-420. http://doi.org/10.1006/anbo.1997.0573

[16] Bento, L.F., Scalon, S.P.Q., Dresch, D.M. and Pereira, Z.V. (2016) Potential of Recovery of Campomanesiaxanthocarpa Mart. ex O. Berg Seedlings from Water Deficit. African Journal of Agricultural Research, 11, 2775-2785. http://doi.org/10.5897/AJAR2016.11231

[17] Li, F., Bao, W., Wu, N. and You, C. (2008) Growth, Biomass Partitioning, and Water-Use Efficiency of a Leguminous Shrub (Bauhinia faberi var. Microphylla) in Response to Various Water Availabilities. New Forests, 36, 53-65. https://doi.org/10.1007/s11056-008-9081-Z

[18] Silva, C.E.M., Gonçalves, J.F.C. and Feldpausch, T.R. (2008) Water-Use Efficiency of Tree Species Following Calcium and Phosphorus Application on an Abandoned Pasture, Central Amazonia, Brazil. Environmental and Experimental Botany, 64, 189-195. https://doi.org/10.1016/j.envexpbot.2008.03.001

[19] Flexas, J., Ribas-Carbó, M., Bota, J., Galmés, J., Henkle, M., Martínez-Cañellas, S. and Medrano, H. (2006) Decreased Rubisco Activity during Water Stress Is Not Induced by Decreased Relative Water Contente But Related to Conditions of Low Stomatal Conductance and Chloroplast $\mathrm{CO}_{2}$ Concentration. New Phytologist, 172, 73-82. https://doi.org/10.1111/j.1469-8137.2006.01794.x

[20] Xu, Z., Zhou, G. and Shimizu, H. (2009) Are Plant Growth and Photosynthesis Limited by Predrought Following Rewatering in Grass? Journal of Experimental Botany, 60, 37-49. https://doi.org/10.1093/jxb/erp216

[21] Herrera, A., Tezara, W., Marín, O. and Rengifo, E. (2008) Stomatal and Non-Stomatal Limitations of Photosynthesis in Trees of a Tropical Seasonally Flooded Forest. Physiologia Plantarum, 134, 41-48. https://doi.org/10.1111/j.1399-3054.2008.01099.x

[22] Chen, H., Zamorano, M.F. and Ivanoff, D. (2010) Effect of Flooding Depth on Growth, Biomass, Photosynthesis and Chlorophyll Fluorescence of Typha domingensis. Wetlands, 30, 957-965. https://doi.org/10.1007/s13157-010-0094-y

[23] Cernusak, L.A., Aranda, J., Marshall, J.D. and Winter, K. (2007) Large Variation in Whole-Plant Water-Use Efficiency among Tropical Tree Species. New Phytologist, 173, 294-305. https://doi.org/10.1111/j.1469-8137.2006.01913.x

[24] Ferreira, M.J., Gonçalves, J.F.C. and Ferraz, J.B.S. (2012) Crescimento e eficiência do uso da água de plantas jovens de castanheira-da-Amazônia em área degradada e submetidas à adubação. Ciência Florestal, 22, 393-401.

https://doi.org/10.5902/198050985747

[25] Baker, N.R. and Rosenqvst, E. (2004) Applications of Chlorophyll Fluorescence Can Improve Crop Production Strategies: An Examination of Future Possibilities. Journal of Experimental Botany, 55, 1607-1621. https://doi.org/10.1093/jxb/erh196

[26] Li, Y.G., Li, L.H., Jiang, G.M., Niu, S.L., Liu, M.Z., Gao, L.M., Peng, Y. and Jiang, C.D. (2004) Traits of Chlororophyl Fluorescence in 99 Species from the Sparse-Elm Grassland in Hunshandak Sandland. Photosynthetica, 42, 243-249. https://doi.org/10.1023/B:PHOT.0000040596.39460.6f 
[27] Zanandrea, I., Nassi, F.L., Turchetto, A.C., Braga, E.J.B., Peters, J.A. and Bacarin, M.A. (2006) Efeito da salinidade sob parâmetros de fluorescência em Phaseolus vulgaris. Revista Brasileira Agrociência, 12, 157-161. https://periodicos.ufpel.edu.br/ojs2/index.php/CAST/article/viewFile/4512/3378

[28] Miao, L.F., Yang, F., Han, C.Y., Pu, Y.J., Ding, Y. and Zhang, L.J. (2017) Sex-Specific Responses to Winter Flooding, Spring Waterlogging and Post-Flooding Recovery in Populus deltoides. Scientific Reports, 7, 1-14. https://doi.org/10.1038/s41598-017-02765-2

[29] Reis, F.O. and Campostrini, E. (2011) Microaspersão de água sobre a copa: Um estudo relacionado às trocas gasosas e à eficiência fotoquímica em plantas de mamoeiro. Revista Brasileira Agrociência, 17, 284-295.

[30] Rohácek, K. (2002) Chlorophyll Fluorescence Parameters: The Definitions, Photosynthetic Meaning, and Mutual Relationships. Photosynthetica, 40, 13-29. https://doi.org/10.1023/A:1020125719386

[31] Oliveira, J.E.Z., Amaral, C.L.F. and Casali, V.W.D. (2008) Caracterização isozimática e atividade de peroxidase em folhas de plantas hiperídrica, intermediária e normal de Bidens pilosa L. mantidas in Vitro. Ciência e Agrotecnologia, 32, 32-36. https://doi.org/10.1590/S1413-70542008000100004

[32] Taiz, L. and Zeiger, E. (2013) Fisiologia Vegetal. 3th Edition, Artmed, Porto Alegre.

[33] Khan, M.N., Sakata, K., Hiraga, S. and Komatsu, S. (2014) Quantitative Proteomics Reveals That Peroxidases Play Key Roles in Postflooding Recovery in Soybean Roots. Journal of Proteome Research, 13, 5812-5828. https://doi.org/10.1021/pr5007476

[34] Kausar, R., Hossain, Z., Makino, T. and Komatsu, S. (2012) Characterization of Ascorbate Peroxidase in Soybean under Flooding and Drought Stresses. Molecular Biology Reports, 39, 10573-10579. https://doi.org/10.1007/s11033-012-1945-9

[35] Oliveira, V.C. and Joly, C.A. (2010) Flooding Tolerance of Calophyllum brasiliense Camb. (Clusianceae): Morphological, Physiological and Growth Responses. Trees, 24, 185-193. https://doi.org/10.1007/s00468-009-0392-2

[36] Egert, M. and Tevini, M. (2002) Influence of Drought on Some Physiological Parameters Symptomatic for Oxidative Stress in Leaves of Chives (Allium schoenoprasum). Environmental and Experimental Botany, 48, 43-49. https://doi.org/10.1016/S0098-8472(02)00008-4

[37] Oliveira, R.B., Lima, J.S., Souza, C.A.M. and Filho, S.M. (2008) Produção de mudas de essências florestais em diferentes substratos e acompanhamento do desenvolvimento em campo. Revista Ciência Agrotécnica, 32, 122-128.

[38] Araújo, E.C., Costa, R.S., Lopes, E.C., Daher, R.F. and Fernandes, M.E.B. (2014) Qualidade das mudas de espécies arbóreas de mangue cultivadas em viveiros e diferentes substrates. Acta Ambiental Catarinense, 11, 21-32. 